\title{
Penggunaan Grup WhatsApp Sebagai Media Pembelajaran Daring selama Pandemi COVID-19
}

\author{
Rani Tiyas Budiyanti ${ }^{1}$, Roro Isyawati Permata Ganggi ${ }^{2}$, Penggalih Mahardika \\ Herlambang ${ }^{3}$
}

1. Fakultas Kesehatan Masyarakat, Universitas Diponegoro, Semarang

2. Fakultas Ilmu Budaya, Universitas Diponegoro, Semarang

3. Fakultas Kedokteran, Universitas Wahid Hasyim, Semarang

\begin{abstract}
ABSTRAK
Latar Belakang : Pandemi Coronavirus Disease -19 (COVID-19) memberikan dampak pada berbagai sektor kehidupan termasuk diantaranya adalah sektor pendidikan. Himbauan mengenai physical distancing selama masa pandemi dan era new normal membuat ranah pendidikan mengoptimalisasikan pembelajaran melalui daring (online). Terdapat berbagai media pembelajaran yang dapat digunakan dalam pembelajaran online, salah satunya dengan memanfaatkan instant messaging seperti Grup WhatsApp. Penelitian ini bertujuan untuk mengetahui efektivitas penggunaan Grup WhatsApp sebagai media pembelajaran selama pandemic COVID-19.

Metode : Penelitian bersifat deskriptif analitik dengan pengumpulan data melalui survei online menggunakan google form. Jumlah responden sebanyak 398 mahasiswa yang telah mendapatkan 3 sesi perkuliahan dengan menggunakan Grup WhatsApp. Waktu penelitian berlangsung pada bulan April hingga Mei 2020.

Hasil : Berdasarkan penelitian, sebanyak 269 responden $(67,6 \%)$ menyebutkan Grup WhatsApp efektif sebagai media pembelajaran, dengan 350 responden $(87,9 \%)$ memiliki nilai post test $\geq 70$. Grup WhatsApp memiliki beberapa keuntungan seperti hemat kuota dan dapat dikombinasikan dengan berbagai fitur pembelajaran. Sedangkan kekurangan dalam media ini adalah mahasiswa mudah terdistraksi dengan chat lain dan sukar diterapkan pada pembelajaran yang melibatkan presentasi mahasiswa.

Kesimpulan : Grup WhatsApp dapat digunakan sebagai alternatif media pembelajaran daring di masa pandemi COVID-19. Meskipun demikian, kombinasi penggunaan teks, gambar, video, dan games perlu dilakukan sehingga dapat memfasilitasi berbagai gaya belajar mahasiswa baik audio maupun visual.
\end{abstract}

Kata Kunci : media pembelajaran; daring; pandemi COVID-19; Grup WhatsApp

\begin{abstract}
Background: Coronavirus Disease -19 (COVID-19) pandemic gives many impacts on various sectors of life including the education sector. Physical distancing's suggestion during the pandemic make the education optimize learning online. There are various learning media that can be used in online learning, one of them is by using instant messaging such as WhatsApp Group. This study aims to determine the effectiveness of using WhatsApp Group as online learning media during the COVID-19 pandemic.

Methods: This research was descriptive analytic research by collecting data through online surveys using Google forms. The number of respondents was 398 students who had received 3 times lecture sessions using WhatsApp Group. Time research was done April to May 2020.

Results: Based on research, 269 students (67.6\%) mentioned that WhatsApp Group was effective as an online learning medium, and supported by 350 students (87.9\%) had a post-test score more than $\geq 70$. WhatsApp Group has several advantages such as saving internet quota and can be combined with various learning features. While this media also has disadvantages such as students easily distracted by other chats and difficult to apply to learning that involves student presentations.

Conclusion: WhatsApp Group can be used as an alternative online learning media during the COVID-19 pandemic and the new normal era. Nevertheless, a combination of the use of text, pictures, videos, and games needs to be done, so it can facilitate various learning styles of students both audio and visual.
\end{abstract}

Keywords: online learning; learning media; COVID-19 pandemic; whatsapp group

Correspondence: dr.Rani Tiyas Budiyanti, MH. Fakultas Kesehatan Masyarakat, Universitas Diponegoro, Semarang, Jawa Tengah, Indonesia. Email : ranitiyas@lecturer.undip.ac.id 


\section{PENDAHULUAN}

Coronavirus Disease-2019 (Covid -19) merupakan penyakit yang disebabkan oleh virus SARS-COV-2 yang telah menjangkiti 216 negara di dunia per 7 Juni 2020. ${ }^{1}$ Penularan virus ini sangat cepat, tercatat sejak kasus pertama dikonfirmasi oleh pemerintah Indonesia pada tanggal 2 Maret 2020 hingga 7 Juni 2020, virus ini telah menginfeksi 30.514 orang. ${ }^{2}$ Covid-19 disinyalir dapat ditularkan melalui droplet sehingga bentuk pencegahan penularan salah satunya dengan menerapkan jaga jarak fisik (physical distancing). Salah satu bentuk penerapan physical distancing adalah dengan memberlakukan kebijakan pembelajaran dari rumah (study from home) melalui pembelajaran daring bagi pelajar dan mahasiswa.

Pembelajaran secara daring pada umumnya memanfaatkan aplikasi online panel discussions seperti Ms. Teams, Zoom, Google Meet, Cisco Webex, Duo, dan sebagainya sebagai media pembelajaran Media ini bersifat synchronous atau real time dan memungkinkan antara pengajar dan siswa dapat bertatap muka face to face. Selain synchronous, pembelajaran juga dapat dilakukan secara asynchronous seperti penggunaan instant messenger (IM) seperti WhatsApp dan Learning Management System. WhatsApp merupakan salah satu IM yang paling banyak digunakan di Indonesia. Kementrian Komunikasi dan Informatika mencatat $83 \%$ dari 171 juta pengguna internet di Indonesia menggunakan aplikasi WhatsApp untuk berkomunikasi. ${ }^{3}$

WhatsApp telah banyak dimanfaatkan masyarakat untuk dapat berkomunikasi baik secara personal maupun grup. Meskipun telah banyak dimanfaatkan sebagai media komunikasi, namun pemanfaatan WhatsApp sebagai media pembelajran masih merupakan sesuatu yang baru, sehingga perlu dilakukan kajian komprehensif. Penelitian ini bertujuan untuk melihat bagaimana pemanfaatan Grup WhatsApp sebagai media pembelajaran selama pandemi Covid19.

\section{METODE}

Penelitian ini merupakan penelitian deskriptif analitik dengan pengumpulan data dengan menggunakan survei online menggunakan google forms. Pertanyaan yang diberikan dalam form merupakan kombinasi pertanyaan tertutup dan terbuka. Responden berjumlah 398 mahasiswa semester 2 yang terbagi dalam 6 kelas dengan kriteria inklusi mengikuti perkuliahan dengan topik Kebijakan Kesehatan selama 3 sesi tatap muka di Fakultas Kesehatan Masyarakat Universitas Diponegoro melalui Grup WhatsApp. Waktu penelitian dilakukan selama bulan April dan Mei 2020.

Perkuliahan dilakukan dengan memanfaatkan fitur yang ada pada Whatsapp yaitu fitur grup chat sebagai forum diskusi atau komunikasi, kamera atau galeri untuk share gambar atau video, fitur share dokumen untuk membagikan file dalam bentuk dokumen baik pdf, .doc, maupun .ppt. Fitur voice note untuk membagikan pesan suara, fitur audio untuk membagikan musik atau rekaman suara, dan youtube video box untuk membagikan video langsung dari youtube.

Perkuliahan melalui Grup WhatsApp diawali dengan penyampaian materi berupa rekaman video perkuliahan, modul, dan suplemen perkuliahan sehari sebelum jadwal perkuliahan dilakukan. Pada jadwal perkuliahan dilakukan presensi, sesi diskusi dan tanya jawab serta post test dan evaluasi melalui Grup WhatsApp. Setting Grup WhatsApp dilakukan 
hanya admin yang dapat menyampaikan pesan, dan hanya dibuka pada saat sesi diskusi sehingga chat tidak tumpang tindih.

Pada sesi diskusi dapat dilakukan dengan penyampaian melalui voice note agar waktu yang digunakan lebih efektif. Selain itu pertanyaan ataupun jawaban yang disampaikan lebih luas dan mendalam sehingga lebih dapat dipahami mahasiswa. Pasca perkuliahan dilakukan post test dalam bentuk soal dan evaluasi mengenai metode atau media pembelajaran yang digunakan melalui Google Form

Data yang diperoleh pada penelitian akan dilakukan cleaning dan disajikan dalam bentuk deskriptif. Data tersebut dianalisis sehingga menghasilkan informasi yang diperlukan

\section{HASIL DAN PEMBAHASAN}

\section{Karakteristik Responden}

Responden dalam penelitian ini merupakan mahasiswa semester 2 yang mengikuti 3 sesi mata kuliah topik Kebijakan Kesehatan. Berdasarkan karakteristik responden, didapatkan data bahwa jumlah laki-laki sebanyak 47 responden dan 351 responden adalah perempuan. Berdasarkan usia, sebaran usia responden antara 17-20 tahun.

\section{Penggunaan Grup WhatsApp sebagai Media Pembelajaran}

Berdasarkan penelitian, sebanyak 269 (67,6\%) menyebutkan Grup WhatsApp efektif sebagai media pembelajaran, sebanyak 128 responden (32,3\%) menyebutkan kurang efektif dan sisanya 1 responden $(0,1 \%)$ menyebutkan tidak efektif (tabel 1). Efektivitas tersebut juga ditunjukkan dengan hasil post test yang menunjukkan sebanyak $350(87,9 \%)$ memiliki nilai post test $\geq 70$ (dalam skala $10-100$ ) dan sebanyak 48 responden $(12,1 \%)$ memiliki nilai post test $\leq 70$ (diagram 2).

Tabel 1. Persepsi responden terhadap penggunaan Whatasapp grup sebagai media pembelajaran

\begin{tabular}{lcc}
\hline \multicolumn{1}{c}{ Respon mahasiswa terhadap } & Jumlah Mahasiswa & Persentase \\
penggunaan Whatsapp & $(\mathrm{n})$ & $(\%)$ \\
\hline Efektif & 296 & 67,6 \\
Kurang Efektif & 128 & 32,3 \\
Tidak Efektif & 1 & 0,1 \\
Total & 398 & 100 \\
\hline
\end{tabular}

Tabel 2. Nilai Post Test Pembelajaran Melalui Grup WhatsApp

\begin{tabular}{ccc}
\hline Nilai Post Tes & Jumlah Mahasiswa $(\mathrm{n})$ & Persentase $(\%)$ \\
\hline$\geq 70$ & 350 & 87,8 \\
$\leq 70$ & 48 & 48 \\
Total & 398 & 100 \\
\hline
\end{tabular}

Penggunaan whatsapp sebagai media pembelajaran dapat digunakan dalam pembelajaran online terutama selama masa pandemi Coronavirus Disease -19 (COVID-19). Hal tersebut ditinjukkan pada hasil penelitian yang menyebutkan bahwa sebagian besar mahasiswa merasa pembelajaran dengan whatsapp efektif didukung dengan nilai ketuntasan minimal yang tercapai pada $87,9 \%$ mahasiswa. 
Penelitian ini sejalan dengan penelitian Sartika (2018) pada mahasiswa Ilmu Komunikasi yang menggunakan whatsapp sebagai media pembelajaran dalam blended learning. ${ }^{4}$ Selain itu, instant messaging ini dinilai mampu menyebarluaskan informasi dengan mudah dan banyak digunakan sehingga informasi lebih dapat tersampaikan.

\section{Keuntungan Penggunaan Grup WhatsApp sebagai Media Pembelajaran}

Dalam pembelajaran melalui Grup WhatsApp, berbagai keuntungan yang dapat diperoleh salah satunya adalah penghematan dalam penggunaan kuota internet. Metode pembelajaran melalui Grup WhatsApp dianggap lebih minim pengeluaran kuota internet dibandingkan dengan tatap muka secara synchrounous atau live.

“Menurut saya cukup efektif dan menghemat kuota internet..” (Responden 393)

"Menurut saya efektif, mengingat domisili saya yang kadang-kadang ada kendala pada jaringan (Responden 361)

“Menurut saya sudah efektif dan tertata serta tidak terlalu boros kuota " (Responden 207)

Selain hemat kuota, pembelajaran melalui Grup WhatsApp juga perlu dikombinasikan dengan pemberian materi pada hari sebelumnya berupa video, powerpoint, dan modul, Selain itu, pada akhir pembelajaran juga dapat diberikan post test atau game pembelajaran sebagai bentuk evaluasi.

“ Menurut saya sudah efektif, apalagi dengan video perkuliahan yang dishare sebelumnya. Sehingga dapat mempelajari terlebih dahulu sebelum sesi diskusi dalam perkuliahan. "(Responden 71)

" Menurut saya sudah efektif karena sebelumnya sudah diberi materi dan video yang berkaitan dengan materi, dan pada saat waktu kuliah digunakan untuk sesi tanya jawab sehingga tidak membuang buang waktu (Responden 50)

Pembelajaran melalui Grup WhatsApp juga perlu memperhatikan metode setting admin grup sehingga perkuliahan menjadi lebih efektif dan tidak tumpang tindih. Pada saat dosen memberikan perkuliahan setting grup dapat disetting hanya admin yang dapat mengirim pesan. Sedangkan pada saat sesi diskusi grup dapat dibuka kembali.

“..Sudah efektif, karena sistem diskusi dijawab dengan voice note yang memudahkan dalam memahami diskusi” (Responden 46)

"Efektif, karena dosen menjelaskan melalui voice note juga, jadi lebih bisa dimengerti”, (Responden 121)

Efektivitas pembelajaran online memang erat kaitannya dengan teknologi yang digunakan. Dalam teori Technology Acceptance Model (TAM) menunjukkan bahwa semakin sering seseorang menggunakan suatu teknologi, maka akan semakin mudah jika informasi disampaikan melalui teknologi tersebut. ${ }^{5}$ Hal ini dikarenakan pengguna lebih familiar sehingga tidak perlu mengalami kesulitan untuk mempelajari penggunaan fitur-fitur pada teknologi yang baru.

Hal tersebut juga menjadi salah satu alasan dari beberapa pengguna ketika merasa kesulitan dalam menggunakan platform Learning Management System yang baru saja dikenalkan karena mereka memerlukan panduan khusus dalam penggunaanya. ${ }^{6}$ 
Menurut Sahidillah \& Miftahurisqqi ( 2019), penggunaan Grup WhatsApp sebagai media pembelajaran juga dapat meningkatkan literasi digital penggunanya. Materi yang disampaikan mlalui video, diskusi melalui voice note, dan teks-teks materi yang disampaikan melalui chat secara tidak langsung akan meningkatkan kapasitas literasi digital dalam mendengar, menulis, memirsa, berbicara, dan membaca. ${ }^{7}$

Dalam taksonomi Bloom,terdapat kategori pencapaian pembelajaran yang terbagi dalam Low Order Thinking serta High Order Thinking. Low order thinking meliputi capaian pembelajaran dalam hal mengingat (remembering) dan mengerti (understanding). Sedangkan high order thinking meliputi menerapkan (applying), menganalisis (analyze), evaluasi (evaluating), dan membuat (creating). ${ }^{8}$

Penggunaan Grup WhatsApp yang dikombinasikan dengan video pembelajaran, modul, penugasan, diskusi, dan game pembelajaran atau evaluasi dapat memacu terpenuhinya pembelajaran dari low order thinking hingga high order thinking. Low order thinking yang dapat muncul adalah pada pencapaian understanding melalui pemahaman video atau modul yang telah diberikan melalui Grup WhatsApp. Selain itu high order thinking dapat tercapai melalui sesi diskusi terkait permasalahan yang relevan dengan mata kuliah yang diberikan. ${ }^{9}$

\section{Hambatan Penggunaan Grup WhatsApp sebagai Media Pembelajaran}

Meskipun memiliki berbagai keuntungan, akan tetapi penggunaan Whats App Grup sebagai media pembelajaran daring juga memiliki ketebatasan. Salah satunya adalah permasalahan distraksi karena menggunakan instant messaging.

"Menurut saya kelemahannya adalah mudah terdistraksi atau kurang fokus" ( Responden 52)

Dalam pembelajaran melalui Grup WhatsApp distraksi dapat menjadi hal yang mengganggu proses pembelajaran. Oleh karena itu, perlu diterapkan strategi dalam pelaksanaan pembelajaran seperti memanggil mahasiswa secara random atau acak untuk menjawab pertanyaan yang diajukan, atau dengan pelaksanaan post test maupun game pembelajaran sehingga mahasiswa tetap fokus pada grup tersebut dan tidak terdistraksi dengan hal lain.

Dalam pelaksanaan pembelajaran, kemampuan admin (pengajar,) dalam mengendalikan kelas melalui setting grup juga diperlukan. Sehingga mahasiswa tidak saling bersahut-sahutan yang menyebabkan chat saling tertumpuk dan alur permbelajaran menjadi tidak terstruktur. Admin harus mampu memoderatori kelas dengan baik dan hanya membuka chat secara umum pada waktu-waktu tertentu.

Selain dapat terdistraksi, kekurangan lain dari whatsapp sebagai media pembelajaran adalah tidak dapat bertatap muka (face to face) secara langsung. Meskipun demikian, pada beberapa mahasiswa ada yang beranggapan bahwa jika perkuliahan tidak dilakukan secara tatap muka langsung (synchrous) maka suasana pembelajaran menjadi kurang terasa.

“ Menurut saya lebih baik menggunakan platform tatap muka langsung sehingga suasana akademik atau pembelajaran menjadi lebih terasa” (Responden 44)

Pembelajaran melalui Grup WhatsApp juga sukar dilakukan jika mahasiswa akan melakukan presentasi langsung. Melainkan mahasiswa harus merekam dahulu dalam bentuk video dan dibagikan ke dalam grup. 
"Pembelajaran melalui Grup WhatsApp efektif menurut saya, tetapi sukar diterapkan jika mahasiswa akan presentasi. Presentasi harus direkam dalam video dahulu.."

Hambatan dalam penggunaan whatsapp juga dikemukakan oleh Wahyuni (2018) dalam proses belajar mengajar di SMK Negeri 2 Banjarmasin. Beberapa hambatan yang dialami diantaranya adalah pengajar tidak mengetahui keseriusan dan minat siswa dalam mengikuti pembelajaran karena tidak dapat melihat gestur atau mimik muka siswa. Selain itu, tidak semua siswa memiliki sarana seperti handphone yang memadai. ${ }^{10}$

\section{KESIMPULAN}

Grup WhatsApp dapat digunakan sebagai media pembelajaran online di masa pandemi COVID-19. Keuntungan yang diperoleh dalam penggunaannya meliputi hemat kuota internet, familiar dengan pengguna, dan mampu meningkatkan literasi mahasiswa. Meskipun demikian, terdapat pula beberapa keterbatasan dalam penggunannya seperti mudahnya distraksi, suasana pembelajaran kurang terasa, dan sukar digunakan pada pembelajaran dimana mahasiswa harus melakukan presentasi langsung. Oleh karena itu, kombinasi dari berbagai media pembelajaran dalam beberapa tatap muka perkuliahan diperlukan sehingga mahasiswa tidak bosan dan level kompetensi dapat tercapai sesuai yang ditargetkan.

\section{DAFTAR PUSTAKA}

1. WHO. Coronavirus Disease (COVID-19) Outbreak Situation. 2020. Diakses dari https://www.who.int/emergencies/diseases/novel-coronavirus-

\section{9? gclid=Cj0KCQjw ez2BRCyARIsAJfg-} ktzcrRFHETNeBDpm8NMtWNrrqCQjKPI9roqqn-IhPqy-BxI_pvUVGgaAj4gEALw_wcB (Diakses : 7 Juni 2020)

2. Gugus Tugas Percepatan Penanganan COVID - 19. Data Sebaran Indonesia. 2020. Diakses dari https://covid19.go.id/(Diakses : 7 Juni 2020)

3. Hutami, Annisa Setya. Kominfo: 83\% Pengguna Internet adalah Pengguna WhatsApp. GATRA. 18 November 2019.

4. Sartika S. Kegunaan WhatsApp sebagai Media Informasi dan Media Pembelajaran pada Mahasiswa Ilmu Komunikasi STISIP Persada Bunda. Medium Jurnal Ilmiah Fakultas Ilmu Komunikasi Universitas Islam Riau. 2018; 6: 2.

5. Nuraryo I, Maliki ND, Meisyaroh S. Jurnalisme Warga: Menjembatani Kesenjangan Penyaluran Kreativitas dan Akses Reportase Media. Jurnal Ilmu Komunikasi. 2015;12:1.

6. Alifiyanti IF, Afifah FH, Ramadoan N. Pemanfaatan Learning Management System (LMS) Berbasis Edmodo Materi Fluida Dinamis untuk Peningkatan Minat dan Prestasi Belajar Fisika Siswa Sekolah Menengah. Prosiding SNFA 2018.

7. Sahidillah, MW \& Miftahurrisqi P. WhatsApp Sebagai Media Literasi Digital Siswa. Varia Pendidikan. 2019. Volume 31 No.1.

8. Sneed, O. Integrating Technology With Bloom 'S Taxonomy - Teach Online. [online] Teach Online. 2016. Diakses melalui : https://teachonline.asu.edu/2016/05/integratingtechnology-blooms-taxonomy/ pada tanggal 10 Juni 2020.

9. Mayisela T. Using Whatsapp in Teaching to Develop Higher Order Thinking Skills-A Literature Review Using the Activity Theory Lens. The International Journal of Education and Development usin Information and Communication Technology. 2019.15 (2): 98-116. 
10. Wahyuni, Nadya. Peran Penggunaan Grup WhatsApp dalam Proses Belajar Mengajar di SMK Negeri 2 Banjarmasin. Muttalaklimin:Jurnal Ilmu Komunikasi. 2018; Vol 1(2): 19-26. Diakses melalui : https://ojs.uniskabjm.ac.id/index.php/mutakallimin/article/view/3411/2289 